\title{
永久磁石による電子サイクロトロン共鳴放電を用いた $\mathrm{CH}_{4} / \mathrm{H}_{2}$ プラズマの成膜への応用*
}

\author{
安井 利明 $* *$. 大家泉**. 村井 晶 $* *$ \\ 田原 弘一**.吉川 孝雄**
}

（受理1996年12月 1 日，掲載決定1997年 1 月11日）

\begin{abstract}
Application of ECR- $\mathrm{CH}_{4} / \mathrm{H}_{2}$ Plasma Using Permanent Magnets to Film Deposition
Toshiaki YASUI, Izumi OYA, Akira MURAI, Hirokazu TAHARA and Takao YOSHIKAWA
\end{abstract}

(Faculty of Engineering Science, Osaka University, Machikaneyama 1-3, Toyonaka, Osaka)

(Received December 1, 1996, Accepted Jonuary 11, 1997)

\section{1. はじめに}

ダイヤモンド薄膜は，その優れた特性から切削工具や 半導体材料など様々な応用が期待されているため, プラ ズマ CVD 法等の成膜法が盛んに研究されている11. 特 に，2.45 GHz のマイクロ波による電子サイクロトロン 共鳴（ECR）放電を用いたプラズマ GVD 法は，他のプ ラズマ GVD 法よりも更に低圧下でダイヤモンド薄膜の 合成が可能であり，また高密度かつクリーンなプラズマ により不純物の混入が少ない良質の薄膜の合成が期待で きる.しかし，ソレノイドュイルを用いた ECR プラズ マ源では, 装置の複雑化・大電力化が避けられず, 大面 積成膜には不向きと考えられる. 本研究室では以前に永 久磁石を用いたプラズマの生成法を研究し，0.1 Pa 以下 の圧力で大面積プラズマの生成の可能性を示した2,3). この永久磁石を用いたECRプラズマ源によりプラズマ CVD 法でダイヤモンドが成膜できれば, 装置を簡素化 ・省電力化できるため大面積成膜が容易になると考えら れる.そこで本研究では，この永久磁石を用いた ECR プラズマ源をダイヤモンド薄膜合成に応用するために, 数 $\mathrm{Pa}$ の圧力下でのプラズマの生成実験を行った。更 に, $\mathrm{H}_{2}$ ガスに $\mathrm{CH}_{4} / \mathrm{H}_{2} / \mathrm{O}_{2}$ ガスを用いて，そのプラズ

* 平成 8 年 10 月 31 日 第 37 回真空に関する連合講演会で講演

** 大阪大学基礎工学部 (厂 560 大阪府豊中市待兼山町 1-3)

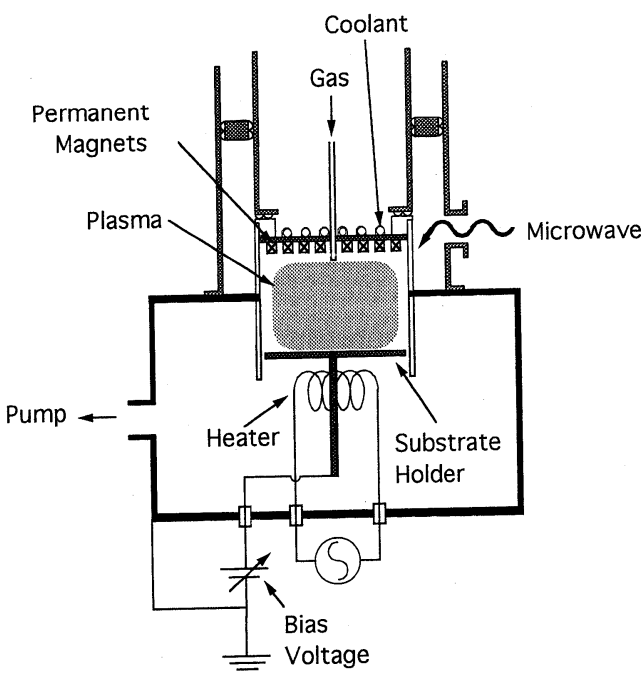

Fig. 1 ECR plasma source for diamond deposition.

マの診断を行うと共に成膜実験を行った.

\section{2. 実験装置}

Fig. 1 に永久磁石を用いた ECR プラズマ源を示す. 放電室は, 内径 $160 \mathrm{~mm}$ の石英ガラス製でその上面に SmCo 磁石 $(10 \times 20 \times 5 \mathrm{~mm})$ がリングカスプ状に 4 列 配置されている．各磁石はステンレス板で覆われてお 
Table 1 Deposition condition

\begin{tabular}{l|c}
\hline \hline Microwave power $(\mathrm{W})$ & 800 \\
Chamber pressure $(\mathrm{Pa})$ & 2.17 \\
Total flow rate $(\mathrm{sccm})$ & 255 \\
$\mathrm{CH}_{4}$ concentration $(\%)$ & 4.0 \\
$\mathrm{O}_{2}$ concentration $(\%)$ & 2.0 \\
Bias voltage $(\mathrm{V})$ & +40 \\
Substrate temperature $\left({ }^{\circ} \mathrm{C}\right)$ & 600 \\
Substrate & $\mathrm{Si}(100)$ \\
\hline
\end{tabular}

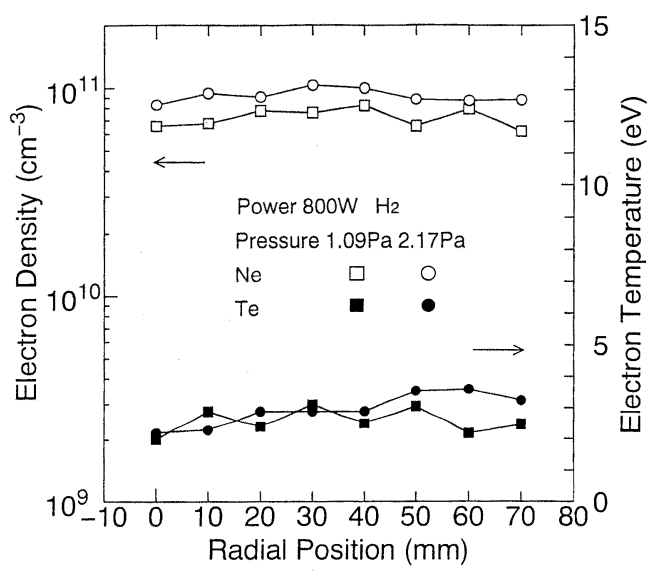

Fig. 2 Spatial profile of plasma at $70 \mathrm{~mm}$ downstream from the magnet surface.

り，その背面を水冷されている．ECR 面 $(87.5 \mathrm{mT})$ は永久磁石表面から約 $6 \mathrm{~mm}$ 下方江平面状牲成され る. $2.45 \mathrm{GHz}$ のマイクロ波は石英ガラス製放電室の側 面から入射され，磁石表面に形成される ECR 領域でプ ラズマを生成する． $\mathrm{H}_{2}$ ガスは放電室上面のガスポート から供給される，基板ホルダーは，放電室下面汇設置さ れて拉り, 磁石表面からの距離は可変となっている。 た基板ホルダーは，その背面から基板に対しバイアス電 圧の印加とヒーターによる加熱ができる構造となってい る.

本研究では，まず $\mathrm{H}_{2}$ ガスを用いて，基板前面でのプ ラズマ密度と電子温度の空間分布を静電単探針で調べ た。また， $\mathrm{CH}_{4} / \mathrm{H}_{2} / \mathrm{O}_{2}$ ガスを用い，プラズマ中で生成 される粒子種を発光分光分析により同定し，その発光強 度の圧力及びガス流量比に対する依存性を調べた，基板 ホルダー中心に測定空を設け，プラズマ中心部での発光 を分光器に導き分光測定を行った. そして最後に, $\mathrm{CH}_{4}$ $/ \mathrm{H}_{2} / \mathrm{O}_{2}$ を用いて成膜実験を行った。 その成膜条件を

Table 1 亿示す。得られた薄膜は, 走査型電子顕微鏡

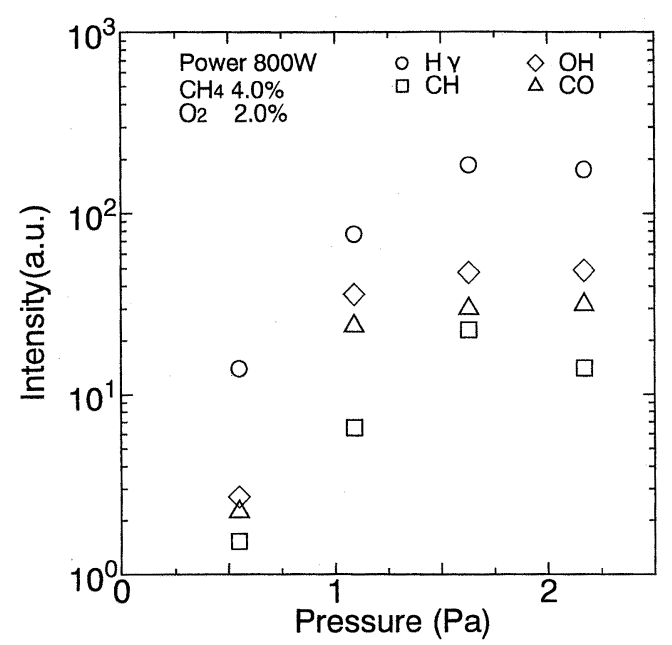

Fig. 3 Peak intensities of emission spectra from plasma for various pressures.

(SEM) 観察 · X 線光電子分光法 $(\mathrm{XPS}) \cdot$ ・ マン分光 法を用いて評価した。

\section{3. 実験結果と考察}

磁石表面から $40 \mathrm{~mm}$ 下方での空間分布は, 壁面近傍 でプラズマ密度及び電子温度が高く, 中心部に向かい減 少していた。 これは $\mathrm{H}_{2}$ ガスの圧力の増加により，マイ ク口波がその入射空の近傍で強く吸収されているためと 考光られる. しかし基板位置が磁石表面から離れるに従 い, 放電室中心部でのプラズマ密度は高くなり, 磁石表 面の下方 $70 \mathrm{~mm}$ 付近で最大となった. この時の空間分 布を Fig. 2 亿示す. 圧力の増加と共飞電子温度は壁面 近傍でやや増加するが，プラズマ密度は放電室全体で一 様である. マイクロ波電力 $800 \mathrm{~W}$, 圧力 $2.17 \mathrm{~Pa}$ の時, 半径70 $\mathrm{mm}$ の領域でカットオフ密度を超える高密度プ ラズマが生成されている，以下の実験では，基板をこの 位置に固定して行った。

$\mathrm{CH}_{4} / \mathrm{H}_{2} / \mathrm{O}_{2}$ ガスを用いてプラズマ中心での発光を測 定した結果, $\mathrm{H} \beta, \mathrm{H} \gamma, \mathrm{CH}, \mathrm{CO}, \mathrm{OH}$ の各スペクトルが 観測された. $\mathrm{H}, \mathrm{OH}$ は非ダイヤモンド相の除去に必要 な粒子と考兄られている. Fig. 3 亿各スペクトルの発光 強度の圧力依存性を示す. 圧力の増加と共に各発光強度 が増加するが， $1.5 \mathrm{~Pa}$ 以上で増加しなくなり，特に $\mathrm{CH}$ の発光強度は $1.5 \mathrm{~Pa}$ 以上で減少する傾向にある. $\mathrm{CH}_{4}: \mathrm{O}_{2}=2: 1$ 亿固定し, $\mathrm{CH}_{4}$ 濃度を変化させた結果 を Fig. 4 亿示す。 $\mathrm{CH}_{4}$ 濃度の増加と共飞 $\mathrm{CH}$ の発光強 度は増加するが, $\mathrm{CO}, \mathrm{OH}$ の発光強度は $5 \%$ を境に減 少している。一方, $\mathrm{H}$ の発光強度は $5 \%$ 以上でやや増 加している. 


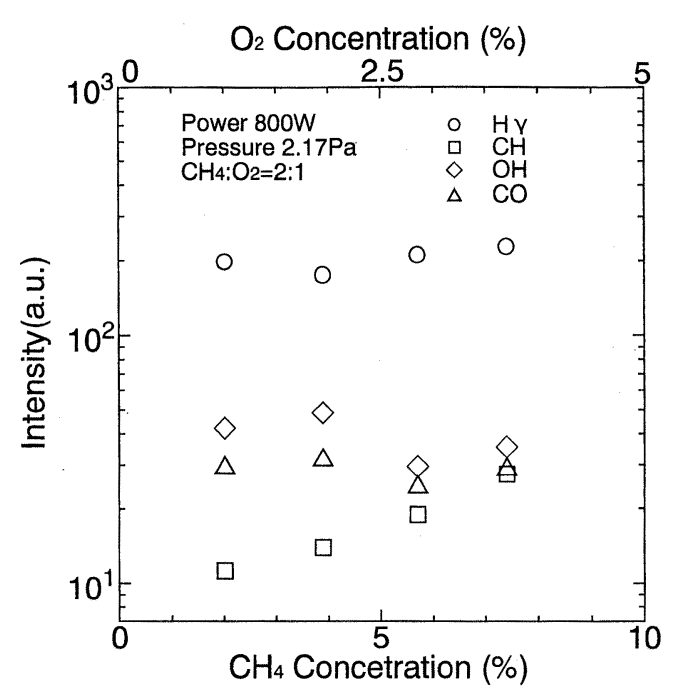

Fig. 4 Peak intensities of emission spectra from plasma for various $\mathrm{CH}_{4}$ concentration.

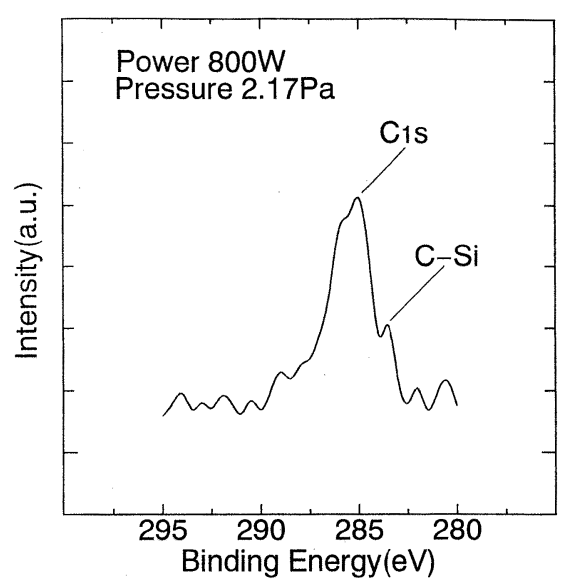

Fig. 5 XPS spectrum for deposited film.

この発光分光分析の実験結果を参考に, Table 1 に示 す成膜条件で 2 時間の成膜実験を行った，得られた薄膜 の表面の XPS 分析の結果を Fig. 5 亿示す. 薄膜表面に $\mathrm{C} 1 \mathrm{~s}$ 結合及び $\mathrm{Si}-\mathrm{C}$ 結合が生成されており， $\mathrm{Si}$ 基板上へ の炭素粒子の堆積が確認された. 特に, $\mathrm{Si}-\mathrm{C}$ 結合のピ

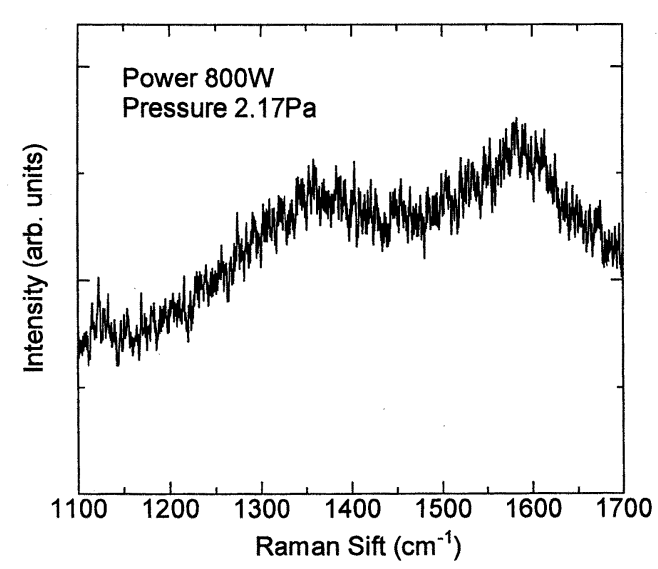

Fig. 6 Raman spectrum for deposited film.

ークはダイヤモンド膜形成の核形成に必要と考えられ る.しかし，SEMによる表面観察からは基板上に結晶 の存在は確認でさなかった. さらにラマン分光分析を行 った結果，Fig. 6 に示すように得られた膜は1350, 1580 $\mathrm{cm}^{-1}$ 付近にピークを持つグラファイトカーボン膜であ った. 基板の加熱温度が $600^{\circ} \mathrm{C}$ とダイヤモンド成膜とし ては低く，非ダイヤモンド相の除去が進まなかったため ではないかと考えられる。

\section{4. まと め}

永久磁石を用いたプラズマ CVD 源により, $\mathrm{H}_{2}$ ガス を用いた実験で圧力 $2.17 \mathrm{~Pa}$ の時, 直径 $160 \mathrm{~mm}$ の領域 で一様かつ高密度プラズマの生成が可能であった. この プラズマ源で $\mathrm{CH}_{4} / \mathrm{H}_{2} / \mathrm{O}_{2}$ ガスを用いて成膜を行ったと ころ, $\mathrm{Si}$ 基板上に $\mathrm{Si}-\mathrm{C}$ 結合をもつグラファイトカーボ ンが成膜された，今後，基板温度を更に上げた成膜実験 を行う予定である.

\section{〔文献〕}

1）田原弘一, 三山彰一, 安井利明, 尾上憲一, 吉川孝 雄 : 高温学会誌, 19 (1993) 160.

2) 安井利明, 中瀬清隆, 田原弘一, 吉川孝雄 : 真空, 38 (1995) 163.

3) T. Yausi, H. Tahara and T. Yoshikawa: J. Vac. Sci. \& Technol. A13 (1995) 2105. 